\title{
ELECTROPHORETIC DEPOSITION OF ALUMINA AND BOEHMITE COATINGS ON METAL SURFACES
}

\author{
Vesna Mišković-Stanković \\ Faculty of Technology and Metallurgy, University of Belgrade, \\ P.O. Box 3503, 11120 Belgrade, Serbia \\ vesna@tmf.bg.ac.rs
}

\begin{abstract}
Electrophoretic deposition (EDP) is gaining increasing attention both in science and industry, due to novel applications in the processing of advanced ceramic materials and ceramic coatings. Electrophoretic deposition has become very interesting because this method has allowed the formation of thin films or multilayer films of controlled thickness and morphology, enabling the formation of films on substrates of complex geometry, aimed for different applications. This review paper represents the mechanism of electrodeposition of ceramic coatings (alumina and boehmite coatings) on metal surfaces, as well as the determination of the optimal deposition parameters (applied voltage, deposition time, electrodeposition bath temperature, suspension concentration) in order to control the thickness and morphology of deposited films. It was shown that coatings of maximum thickness, low porosity and good adhesion were obtained at lower deposition voltages and for longer deposition times.
\end{abstract}

Key words: electrophoretic deposition; coatings; alumina; boehmite

\section{ЕЛЕКТРОФОРЕТСКА ДЕПОЗИЦИЈА НА ТЕНКИ СЛОЕВИ ОД АЛУМИНИУМ ОКСИД И БЕМИТ НА МЕТАЛНИ ПОВРШИНИ}

Електрофоретската депозиција (EDP) го привлекува вниманието и во науката и во индустријата заради нови апликации во развивањето нови керамички материјали и керамички тенки слоеви. Електрофоретскта депозиција е значајна бидејќи овој метод овозможува образување тенки филмови и повеќеслојни филмови со контролирана дебелина и морфологија, со што се овозможува добивање филмови на супстрати со комплексна геометрија и за различни цели. Во овој преглед е прикажан механизмот на електродепозицијата на керамички тенки слоеви (алумина и бемит) на метални површини, како и определувањето на оптималните параметри (применет електричен напон, време на депозиција, темепратура на бањата за депозиција, концентрација на суспензијата) со кои се контролира дебелината и морфологијата на нанесениот филм. Покажано е дека тенки слоеви со најголема дебелина, мала порозност и добра атхезија се добиваат при ниски електрични напони на депозиција и поголеми времиња на нанесување.

Клучни зборви: електрофоретска депозиција; тенки слоеви; алумина; бемит 


\section{INTRODUCTION}

Electrophoretic deposition (EPD) is gaining increasing attention as a powerful method for the formation of both uniform thin and thick films on substrates of complex geometry [1-12]. This method is used worldwide for the deposition of organic protective coatings $[6-9,13]$, ceramic coatings [10-12], bioceramic coatings $[1-4,14-17]$ and composite coatings [5, 18-20]. There are various methods to deposit ceramic coatings on metal surface, such as plasma spraying, sputtering, pulsed laser-deposition, sol-gel, electrophoresis and electrodeposition [21]. Among these, electrophoretic deposition (EPD) emerges as a method of choice due to its simple set-up and formation of uniform coatings, even on substrates of complex shape [22-26]. Other advantages are that EPD is an inexpensive electrochemical technique that can be carried out at room temperature with the possibility of reputable control of coating thickness and morphology by adjusting deposition parameters. This method is used worldwide due to the relative simple process equipment and relative low production costs. The thickness and structure of deposited films can be easily controlled by changing the deposition parameters, i.e. applied voltage, deposition time and particles concentration in suspension, while mechanical characteristics are good [27].

Electrophoretic deposition is a phenomenon associated with the motion of charged particles dispersed in a liquid towards an electrode under an applied electric field (electrophoresis) and deposit formation occurs by particle coagulation. The majority of the work on electrophoretic deposition has been done in non-aqueous medium [28-32]. The reason was that non-aqueous medium had much better performances in respect to aqueous medium (e. g. low viscosity, good chemical stability). On the other hand, one of the major drawbacks associated with use of organic medium is that it is "environmentally unfriendly". That was the reason that electrophoretic deposition method is performed in aqueous solution when ever possible [24, 28, 33, 34]. The use of solgel routes in ceramic processing has many advantages, such as greater purity, higher homogeneity and ultrafine grain size distribution, in comparison to conventional powder-based processing techniques. Moreover, as the sol contains very sinter-active ceramic particles on a nanometer scale, the sintering temperatures can be lowered by several hundred degrees [35].

The aim of this work was to present the optimal process parameters (applied voltage, deposition time, electrodeposition bath temperature and suspension concentration) for deposition of alumina and boehmite coatings from aqueous suspensions using sol-gel routes in order to obtain the greatest thickness and the lowest porosity on deposited ceramic films.

\section{ELECTROPHORETIC DEPOSITION OF ALUMINA AND BOEHMITE COATINGS}

The necessary condition that provides successful electrophoretic deposition (EPD) is a stable suspension/sol, in which the particles have a high zeta potential, while the ionic conductivity of the suspension is kept at a low value [36]. Factors influencing the EPD process are: electrical conditions (voltage and time) and parameters related to suspension (particle charging, solid loading, dispersants, suspension viscosity, particle size distribution).

According to proposed mechanism [3740], the alumina deposition process occurs in several steps. Positively charged oxide particles/lyosphere system (e. g. $\left[\mathrm{M}-\mathrm{OH}_{2}\right]^{+} \mathrm{X}^{-}$) migrate toward the cathode. The rate of migration that the particles can achieve, $v$, depends on applied electric field, $E$, suspension viscosity, $\eta$, particle radius, $r$, and particle charge, $z$, and is given by the following equation [38]:

$$
v=z E / 6 \pi \eta r
$$

indicating the linear dependence of migration rate upon applied electric field. When ion comes to the cathode, it discharges. Because 
the particle is close enough to the cathode, attractive forces dominate and coagulation/ deposition occurs. At the same time, the hydrogen evolves on the cathode and oxygen on the anode:

cathode:

$$
\begin{gathered}
2 \mathrm{H}_{2} \mathrm{O}+2 \mathrm{e}^{-} \rightarrow \mathrm{H}_{2}+2 \mathrm{OH}^{-}(\mathrm{pH} 7-14) \\
\text { or } 2 \mathrm{H}^{+}+2 \mathrm{e}^{-} \rightarrow \mathrm{H}_{2}(\mathrm{pH} 1-7)
\end{gathered}
$$

anode:

$$
2 \mathrm{H}_{2} \mathrm{O} \rightarrow 4 \mathrm{H}^{+}+\mathrm{O}_{2}+4 \mathrm{e}^{-}
$$

Evolved hydrogen goes out through the coating, leaving the vacancies inside the deposited alumina film and causing its porous structure.

Adsorption and desorption processes can be represented as follows in the case of boehmite particles $[11,25]$ :

$$
\begin{aligned}
& >\mathrm{AlOH}+\mathrm{H}^{+} \leftrightarrows>\mathrm{AlOH}_{2}^{+} \quad\left(\mathrm{pH}<\mathrm{pH}_{\mathrm{pzc}}\right) \quad(5) \\
& >\mathrm{AlOH}+\mathrm{OH}^{-} \leftrightarrows>\mathrm{AlOH}^{-}+\mathrm{H}_{2} \mathrm{O} \quad\left(\mathrm{pH}>\mathrm{pH}_{\mathrm{pzc}}\right)
\end{aligned}
$$

The electrophoretic deposition of boehmite particles occurs in several steps and has been discussed in literature in detail $[11,25$, $27,28]$. The rate of migration that the particles can achieve is given by the eq. (1). When an ion reaches the cathode, it discharges. As the particle is sufficiently close to the cathode, attractive forces dominate and coagulation/ deposition occurs. During electrodeposition, the hydrogen evolved according to eq. (2) bubbles on the cathode and diffuses through out the deposited boehmite film. In addition, some hydrogen bubbles may remain trapped between the deposited sol particles, leading, in both cases, to film porosity [41]. Indeed, the dependence of the deposition current density on the deposition time at constant applied voltage in our previously published paper [11], corresponded to the deposition of porous films because current density did not achieve zero value during electrodeposition, suggesting that the coating is still porous and that particle deposition still occurs [42].

\section{ALUMINA COATINGS}

The solid phase content of alumina powder in water suspension was 10, 20 and $30 \mathrm{wt}$. $\%$. The alumina films were electrodeposited on steel from the water suspensions of alumina powder using constant voltage method. The experiments were performed at different values of constant voltage between 30 and 90 $\mathrm{V}$, during different deposition time between 1 and $10 \mathrm{~min}$ and over temperature range of $20-40{ }^{\circ} \mathrm{C}$ [24].

The optical microscopy coupled with the quantitative image analysis is useful technique used for surface characterization of alumina films electrodeposited on steel. The stereo microscope with excellent depth of the field sharpness and with variable magnitude up to $200 \times$ was used as a source of visual information, being very suitable for nondestructive measurements on fragile alumina deposits. The advantage of using optical microscopy coupled with image analyzer is the statistical analysis of the obtained results which enables the determination of the pore number, percentage of the film surface covered by pores and mean pore diameter. The finer microstructure of alumina films was investigated using scanning electron microscopy (SEM) [24].

It was shown [24] that increase in applied deposition voltage over $100 \mathrm{~V}$ decreases the alumina film thickness and increases the film porosity due to larger amount of evolved hydrogen on cathode (eq. 2) which goes out through the coating, leaving more vacancies in the film and causing more porous structure. For this reason, the experiments were performed over lower range of deposition voltage between 30 and $90 \mathrm{~V}$. The effect of applied depostion voltage and concentration of alumina powder in water suspension on the percentage of alumina film surface covered by pores, $A_{\mathrm{p}}$, is shown in Figure 1 [40]. 


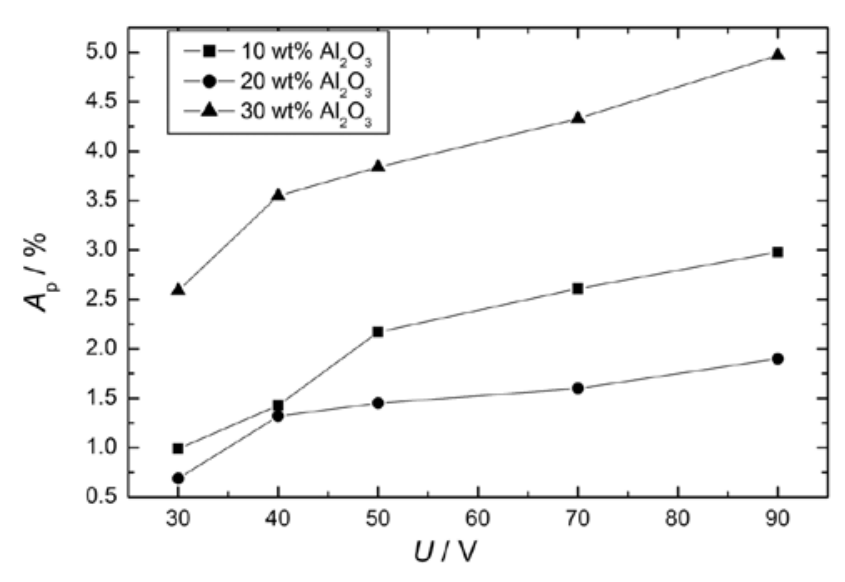

Fig. 1. The percentage of alumina film surface covered by pores vs. applied deposition voltage for different concentration of alumina powder in suspension (deposition time $10 \mathrm{~min}$ )

It can be observed that the films obtained from $20 \mathrm{wt} . \%$ of alumina powder in suspension have the lowest porosity for all applied deposition voltages. This can be explained by the optimal ratio of number of suspended particles and number of water molecules, which enables the best particle dispersion and consequently, the best particle packing on the cathode during deposition process. The films obtained from $10 \mathrm{wt} . \%$ and $30 \mathrm{wt} . \%$ suspension have greater porosity due to larger amount of evolved hydrogen (in the case of $10 \mathrm{wt} . \%$ suspension) or due to agglomerates detected (in the case of 30 wt.\% suspension). On the other hand, the increase of applied voltage increases the percentage of film surface covered by pores (Figure 1) due to larger amount of evolved hydrogen on the cathode at higher voltages. The minimum values of the alumina film surface covered by pores, $A_{\mathrm{p}}$ (Figure 1), pore number, $N$, and mean pore diameter, $D_{\mathrm{p}}$, were obtained for deposition voltage of $30 \mathrm{~V}$ and $20 \mathrm{wt} . \%$ of alumina powder in water suspension while the thickness of this alumina film is $40 \mu \mathrm{m}$ [40].

The effect of deposition time on alumina film thickness and morphology was investigated for films electrodeposited from $20 \mathrm{wt} . \%$ suspension at 30, 40 and $50 \mathrm{~V}$. At lower applied voltages (30 and $40 \mathrm{~V}$ ), the increase in deposition time increases the alumina film thickness

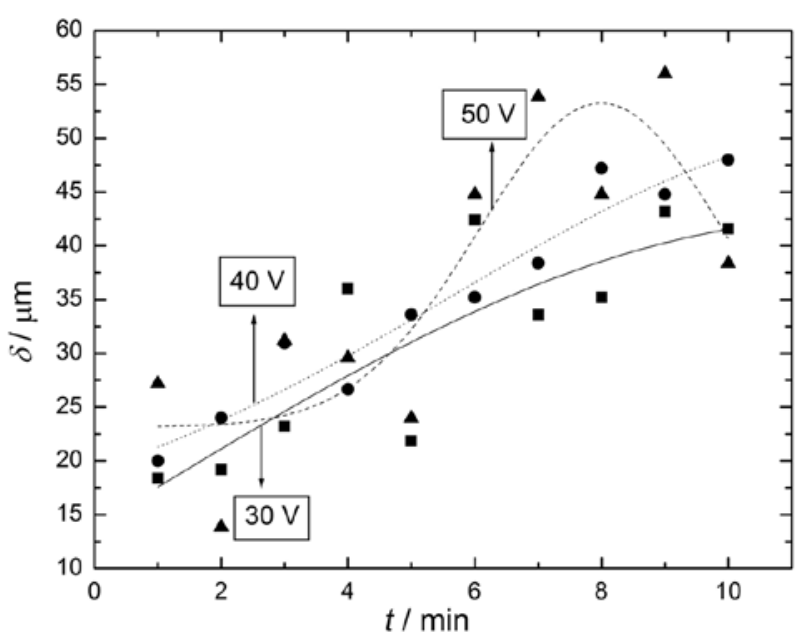

Fig. 2. Dependence of alumina film thickness on deposition time for $20 \mathrm{wt} . \%$ alumina suspension at different applied voltages

(Figure 2) due to much more particles which reach the cathode and discharge on it.

For longer deposition time, at higher applied voltages $(50 \mathrm{~V})$ the film thickness achieves a maximum and then decreases due to larger amount of evolved hydrogen, which accumulates on the cathode and causes more vacancies in the deposited film. This explains the greater values of pore number, percentage of alumina film surface covered by pores and mean pore diameter (Figure 3) for alumina films electrodeposited at higher voltages and for longer deposition time [40].

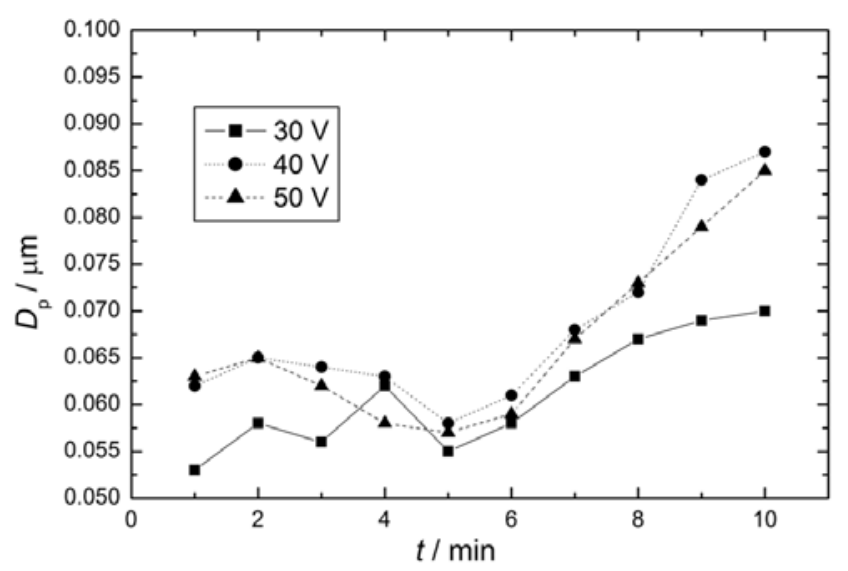

Fig. 3. The mean pore diameter vs. deposition time for $20 \mathrm{wt} . \%$ alumina suspension at different applied voltages 
Since the increase in deposition time does not increase the film porosity significantly at the lowest deposition voltage of $30 \mathrm{~V}$ (Figure 3), and on the other hand significantly increases the film thickness (Figure 2), it can be concluded that optimal deposition time is $10 \mathrm{~min}$, for applied voltage of $30 \mathrm{~V}$ and $20 \mathrm{wt} . \%$ suspension, while the coating exhibited good adhesion.

The temperature dependence of pore number, $N$ (Figure 4 ), pore area, $A_{\mathrm{p}}$, and percentage of film surface covered by pores show the minimum at $30{ }^{\circ} \mathrm{C}$ for all deposition times, while the mean pore diameter, $D_{\mathrm{p}}$, doesn't depend on bath temperature and deposition time significantly [39].

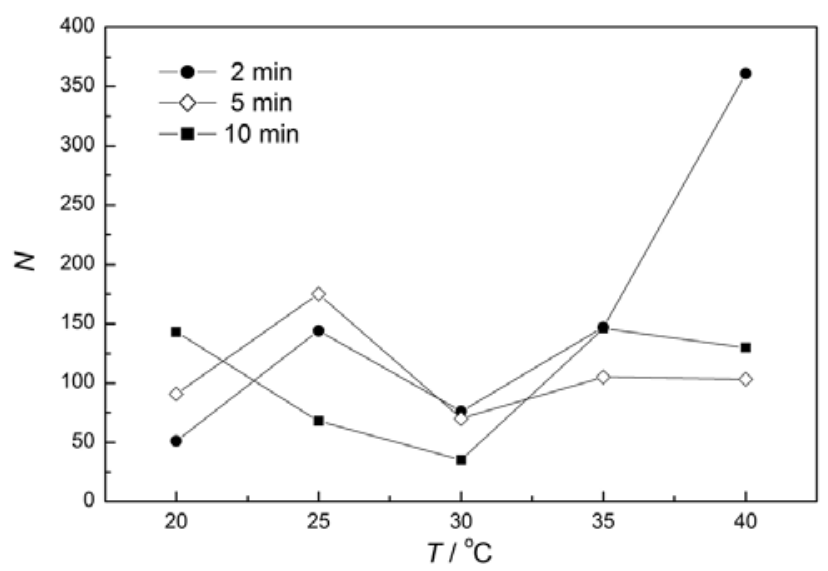

Fig. 4. Dependence of pore number on bath temperature for $20 \mathrm{wt} . \%$ alumina suspension and different deposition time

This behavior can be explained by the proposed mechanism of alumina deposition process, which occurs in several steps, as was mentioned earlier. The increase in bath temperature decreases the viscosity of water suspension, and consequently increases the rate of particles migration according to eq. (1). On the other hand, the rate of the hydrogen evolution reaction (eq. (2)) as an undesirable process, increases with increasing bath temperature, also. At $30^{\circ} \mathrm{C}$ these two processes, particle migration and coagulation and hydrogen evolution, are in equilibrium, which results in the minimum porosity of deposited films, e. g. minimum values of pore number (Figure 4), pore area and per- centage of film surface covered by pores. It can be noticed also that the minimum values of these parameters were obtained for deposition time of $10 \mathrm{~min}$. This means that optimal deposition time is $10 \mathrm{~min}$ and during this time the alumina film of the lowest porosity and the highest thickness was formed. Namely, for longer deposition time (10 min) there are much more particles which reach the cathode, and consequently the film thickness increases. On the other hand, the possibility of their better packing on the cathode is greater, so the film porosity is decreased.

At temperatures lower than $30{ }^{\circ} \mathrm{C}$, the particles migration is too slow although the rate of hydrogen reaction is low, which causes the bad packing of alumina particles and greater porosity of obtained films. On the other hand, at temperatures higher than $30^{\circ} \mathrm{C}$ the particles migration is fast but, the hydrogen evolution is too fast also. As a consequence, the greater amount of evolved hydrogen goes out through the film, leaving more vacancies inside the films and causing the more porous structures (Figure 4).

The structure of alumina film surface obtained under optimal deposition conditions, i. e. applied voltage $30 \mathrm{~V}, 20 \mathrm{wt} . \%$ alumina powder in suspension, bath temperature $30{ }^{\circ} \mathrm{C}$ and deposition time $10 \mathrm{~min}$, is shown in Figure 5 [39].

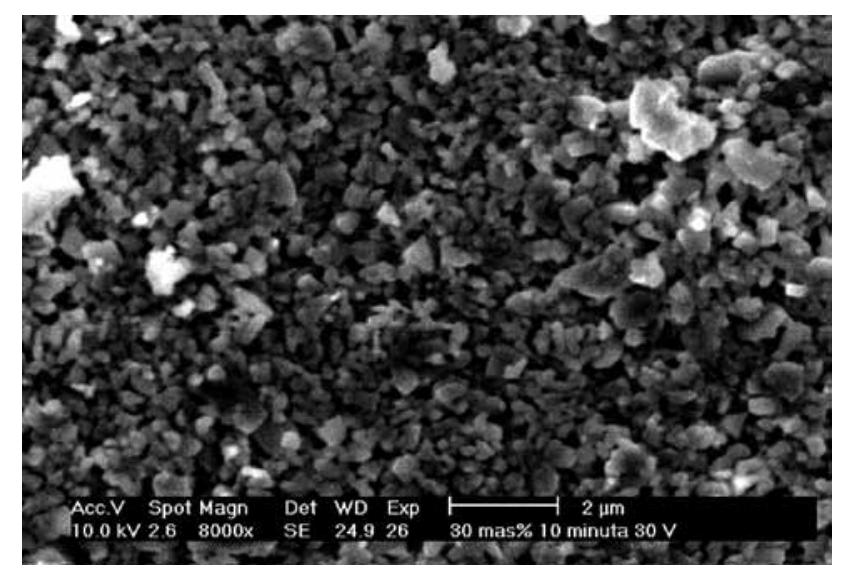

Fig. 5. The microphotograph of alumina film surface obtained from $20 \mathrm{wt} . \%$ of alumina powder in suspension, at $30 \mathrm{~V}$ and $30^{\circ} \mathrm{C}$ (deposition time $10 \mathrm{~min}$ ) 


\section{BOEHMITE COATINGS}

Boehmite sol was prepared by the peptization of freshly precipitated $\mathrm{Al}(\mathrm{OH})_{3}$, obtained by the addition of $\mathrm{NH}_{4} \mathrm{OH}$ to $\mathrm{AlCl}_{3} \times 6 \mathrm{H}_{2} \mathrm{O}$ aqueous solution at $80{ }^{\circ} \mathrm{C}$ up to $\mathrm{pH} 7-8$. The precipitate was then washed with hot water until a negative reaction of $\mathrm{Cl}^{-}$ions with $\mathrm{AgNO}_{3}$ was observed. $\mathrm{Al}(\mathrm{OH})_{3}$ was suspended in distilled water and the appropriate amount of concentrated $\mathrm{HNO}_{3}$ acid was added at a molar $n\left(\mathrm{HNO}_{3}\right) / n\left(\mathrm{Al}(\mathrm{OH})_{3}\right)$ ratio of 0.1 . The sol was prepared under reflux at $100{ }^{\circ} \mathrm{C}$ for $48 \mathrm{~h}$. Boehmite powder was obtained by drying the sol at $90{ }^{\circ} \mathrm{C}$ for $48 \mathrm{~h}$. The solid phase content, determined gravimetrically, was $1.76 \mathrm{wt} \%$ [11, 25].

Boehmite coatings were deposited on titanium from aqueous boehmite sol using the constant voltage method. The experiments were performed at different values of constant voltage ranging between 1.0 and $10 \mathrm{~V}$, for various deposition times of $10-30 \mathrm{~min}$ at room temperature. Boehmite coatings were characterized by thermogravimetric analysis (TGA) and scanning electron microscopy (SEM). The microstructure of the boehmite coatings dried at room temperature in air and coatings sintered in air at $1000^{\circ} \mathrm{C}$ and $1300{ }^{\circ} \mathrm{C}$ for $1 \mathrm{~h}$ was examined by SEM $[11,25]$.

The mass of the boehmite deposit, $m$, as a function of the applied deposition voltage, $U$, for different deposition times is shown in Figure 6 [25].

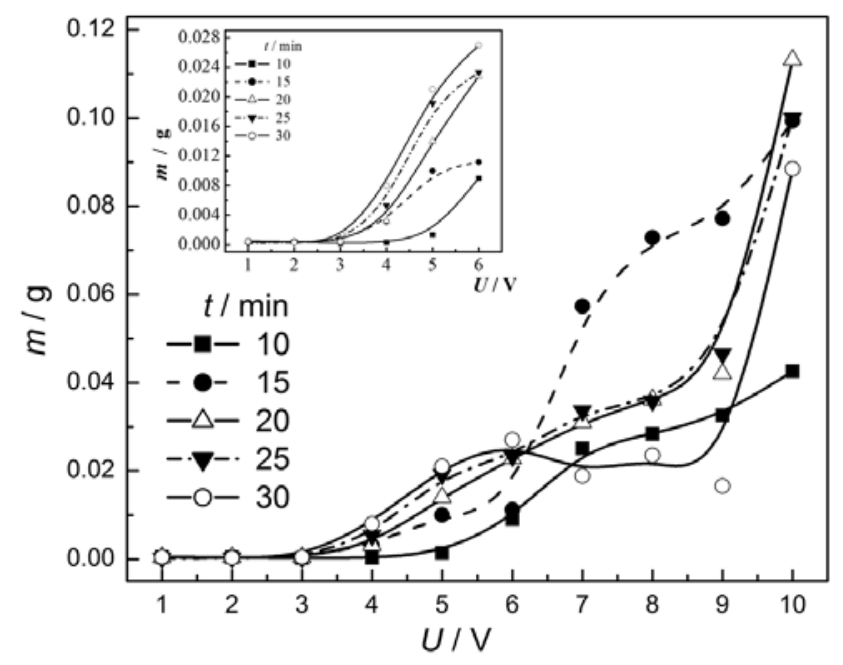

Fig. 6. Dependence of the boehmite deposit mass on the applied voltage for different deposition times. Inset: $m$ vs. $U$ curves at voltages up to $6.0 \mathrm{~V}$
The increase in applied voltage and deposition time increases the boehmite deposit mass. According to eq. (1), the increase in applied voltage increases the rate of particle migration and, consequently, the mass of boehmite deposit. The rate of hydrogen evolution, as an undesirable process, also increases with increasing applied voltage. At lower applied voltages, up to $3.0 \mathrm{~V}$, the mass of the boehmite deposit is too small and the deposition time, as well as the deposition voltage, does not influence the process (inset in Figure 6). A possible explanation is that the applied electric field is not sufficiently strong and that the rate of colloidal particle migration is too slow. At the same time, the applied voltage is insufficient to cause a destabilization of the boehmite sol near the electrode.

An increase in the applied voltage from 3.0 to $6.0 \mathrm{~V}$, for all deposition times, increases the mass of the boehmite deposit (inset in Figure 6). Also, the rate of hydrogen evolution increases at higher applied voltages greater than $3.0 \mathrm{~V}$, so the amount of evolved hydrogen is larger, causing greater porosity and cracks in the boehmite deposit during subsequent drying at room temperature. Poor adhesion of the boehmite deposit was observed at applied voltages higher than $4.0 \mathrm{~V}$, although the mass of boehmite deposit increased.

A decrease in the mass of the boehmite deposit was observed at voltages higher than $6.0 \mathrm{~V}$ for a deposition time of $30 \mathrm{~min}$. This behavior can be explained by a larger amount of hydrogen evolved at the cathode at higher voltages and for longer deposition times, and additionally, by poor adhesion of boehmite coating.

The effect of deposition time on the mass of the boehmite deposit at different applied voltages is also shown in Figure 6. At lower applied voltages, up to $3.0 \mathrm{~V}$, an increase in the deposition time does not influence the mass of the boehmite deposit. At applied voltages from $3.0 \mathrm{~V}$ to $6.0 \mathrm{~V}$, increasing deposition time increases the mass of boehmite deposit due to more particles reaching the cathode. At voltages higher than $6.0 \mathrm{~V}$ the mass of the boehmite deposit achieves a maximum and then decreases with increasing deposition time due to the 
larger amount of evolved hydrogen, which accumulates on the cathode and forms more pores in the deposited film.

Thus it may be concluded that the optimal deposition voltage for the boehmite coating is $4.0 \mathrm{~V}$, because it is the highest voltage at which a film of low porosity and good adhesion can be formed on titanium. On the other hand, the optimal deposition time is $30 \mathrm{~min}$, since an increase in the deposition time increases the mass of the boehmite deposit. Consequently, boehmite coatings of maximum thickness, low porosity and good adhesion were formed for longer deposition times and at lower deposition voltages. A coating electrodeposited at $4.0 \mathrm{~V}$ and for a deposition time of $30 \mathrm{~min}$ was chosen for further thermal treatment at 1000 and $1300{ }^{\circ} \mathrm{C}$ with a holding period of $1 \mathrm{~h}$ at the maximum temperature.

The weight loss and temperatures associated with phase transformations were determined by thermogravimetric analysis. Figure 7 represents the differential TG (DTG) curve of the boehmite coating $(U=4.0 \mathrm{~V}, t=30 \mathrm{~min}$, dried at room temperature) obtained in the temperature range between 23 and $600{ }^{\circ} \mathrm{C}$ [25].

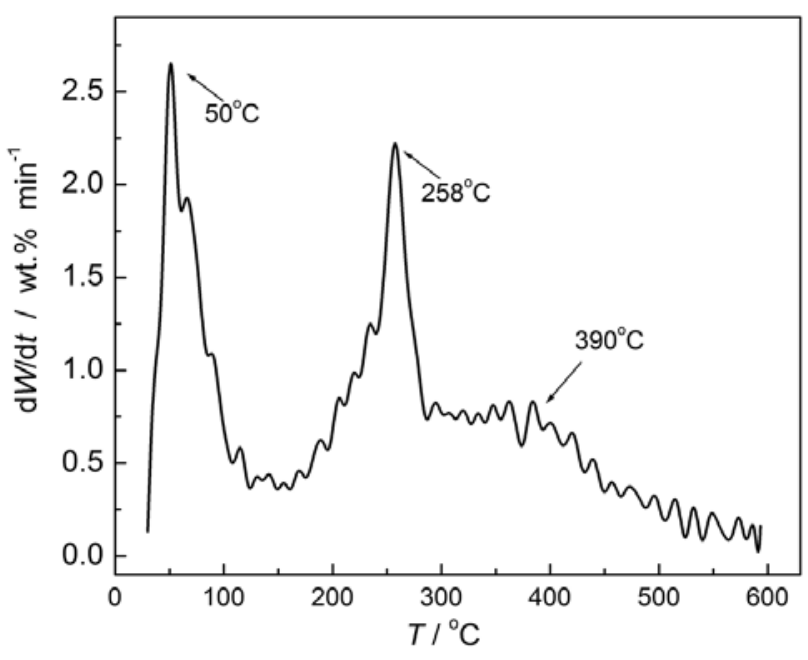

Fig. 7. Differential TG (DTG) curve of the boehmite coating

( $U=4.0 \mathrm{~V}, t=30 \mathrm{~min}$, dried at room temperature in air)

The TG curve of boehmite coating exhibited three characteristic weight loss stages. The first stage was observed from $23{ }^{\circ} \mathrm{C}$ to $160{ }^{\circ} \mathrm{C}$, with a sharp peak at $50{ }^{\circ} \mathrm{C}$ in the DTG curve. This stage corresponds to the desorption of water molecules adsorbed on the crystallites surface. The weight loss in this stage in the initial pseudoboehmite was calculated to be $13 \mathrm{wt} . \%$. This is in accordance with data from the literature [41], which showed that the weight loss in pseudoboehmite is higher than the weight loss in boehmite (about 1 wt.\% in boehmite) due to the smaller crystallite size and thus a higher surface area avaliable for water adsorption.

The second stage of weight loss of the TG curve was observed between 160 and $450{ }^{\circ} \mathrm{C}$, which corresponds to the transition of boehmite into $\gamma-\mathrm{Al}_{2} \mathrm{O}_{3}$, while two peaks in the DTG curve were observed in this temperature interval: a sharp peak at $258^{\circ} \mathrm{C}$ and a wide peak at $390{ }^{\circ} \mathrm{C}$ (Figure 7). The peak at $258^{\circ} \mathrm{C}$ and a weight loss of 11 wt. $\%$ between 50 and $258^{\circ} \mathrm{C}$, calculated from the TG curve, indicate the transformation of pseudoboehmite $\left(\mathrm{Al}_{2} \mathrm{O}_{3} \times n \mathrm{H}_{2} \mathrm{O}\right.$, where $1<n<2.5)$ into boehmite $\left(\mathrm{Al}_{2} \mathrm{O}_{3} \times \mathrm{H}_{2} \mathrm{O}\right)$ [43-49] and corresponds to $0.41 \mathrm{~mol} \mathrm{H}_{2} \mathrm{O}$ per mol boehmite. Consequently, the formula of the starting pseudoboehmite was calculated to be $\mathrm{AlOOH} \times 0.41 \mathrm{H}_{2} \mathrm{O}$ or $\mathrm{Al}_{2} \mathrm{O}_{3} \times 1.82 \mathrm{H}_{2} \mathrm{O}$. The excess water in pseudoboehmite is not surface layer, but interlayer water. The weight loss of 15 wt. $\%$ between 258 and $390{ }^{\circ} \mathrm{C}$, calculated from the TG curve, is associated with further boehmite transformation to $\gamma-\mathrm{Al}_{2} \mathrm{O}_{3}$ according to the equation:

$$
2 \mathrm{AlOOH} \rightarrow \gamma-\mathrm{Al}_{2} \mathrm{O}_{3}+\mathrm{H}_{2} \mathrm{O}
$$

and corresponds to the theoretical weight loss of 15 wt.\% [49]. The second, wide peak at $390{ }^{\circ} \mathrm{C}$ (Figure 7) corresponds to the transition from boehmite into $\gamma-\mathrm{Al}_{2} \mathrm{O}_{3}$, which occurs through partial dehydroxylation as a consequence of broken hydrogen bonds between the double layers in the boehmite crystallites [41, 49]. The total weight loss of $26 \mathrm{wt} \%$ in the second stage of the TG curve between 50 and $450{ }^{\circ} \mathrm{C}$ confirms the transformation from pseudoboehmite to $\gamma-\mathrm{Al}_{2} \mathrm{O}_{3}$.

The third stage of negligible weight loss at temperatures above $450{ }^{\circ} \mathrm{C}$ (Figure 7) cor- 
responds to the transformation of $\alpha-\mathrm{Al}_{2} \mathrm{O}_{3}$ into the most stable $\gamma-\mathrm{Al}_{2} \mathrm{O}_{3}$ via a sequence of transitional aluminas $\gamma \rightarrow \delta \rightarrow \theta \rightarrow \alpha-\mathrm{Al}_{2} \mathrm{O}_{3}$. This transition is a consequence of the continuous and gradual loss of residual hydroxyl groups and involves a reorganization of the oxygen into a denser, hexagonal closely packed configuration by nucleation and growth [49].

The same results of phase transformations and calculated values of weight loss between three characteristric weight loss stages, as well as the calculated formula of the starting pseudoboehmite, were obtained from TGA of boehmite powder [11], indicating the same structure of boehmite coatinig and boehmite powder, with no effect of the substrate on the boehmite coating structure.

Figure 8 represents the SEM micrograph of the boehmite coating treated at $1000{ }^{\circ} \mathrm{C}$ for $1 \mathrm{~h}$ [25]. According to analysis of XRD pattern of boehmite powder treated at the same way [11] it could be concluded that the boehmite coating is also $\gamma$-alumina, having in mind the results obtained from TGA for both powder and coating.

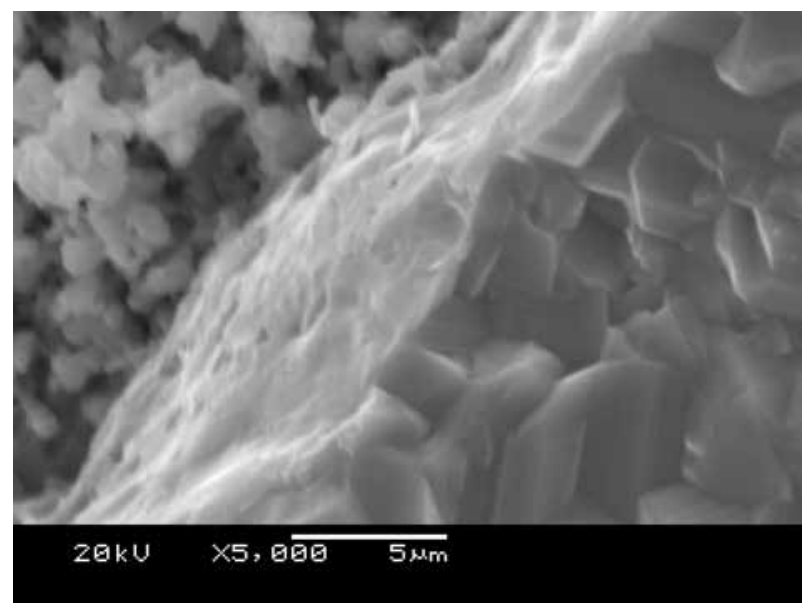

Fig. 8. SEM micrograph of the boehmite coating $(U=4.0 \mathrm{~V}, t=30 \mathrm{~min})$ sintered at $1000{ }^{\circ} \mathrm{C}$

The SEM micrograph of the boehmite coating treated at $1300{ }^{\circ} \mathrm{C}$ for $1 \mathrm{~h}$ (Figure 9) [25] shows the graininess of the coating of $\alpha-\mathrm{Al}_{2} \mathrm{O}_{3}$, which is in accordance with the XRD data of boehmite powder treated at the same temperature [11], having in mind the results ob- tained from TGA for both powder and coating. This indicates the lower sintering temperature of the boehmite coating obtained by the sol-gel procedure compared to sintering temperature $\left(1600{ }^{\circ} \mathrm{C}\right)$ of the boehmite coatings obtained by classical forming methods [50].

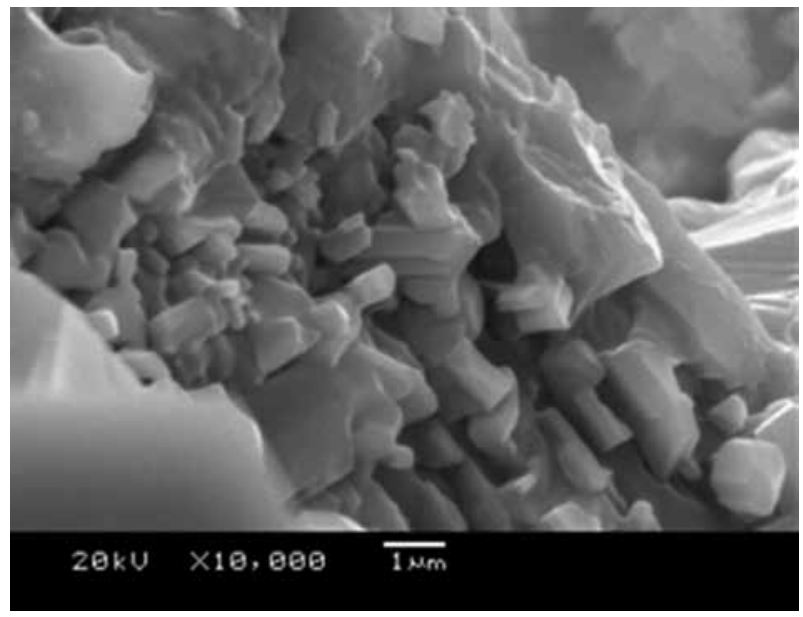

Fig. 9. SEM micrograph of the boehmite coating $(U=4.0 \mathrm{~V}, t=30 \mathrm{~min})$ sintered at $1300{ }^{\circ} \mathrm{C}$ (magnification 10000×).

Based on the all presented results, it is important to emphasize that optical microscopy coupled with image analysis gave information about morphology of alumina and boehmite coatings, i.e. pore number, mean pore diameter and percentage of film surface covered by pores and consequently, enabled the determination of the optimal deposition parameters (aplied voltage, deposition time, concentration, bath temperature) in order to obtaine the coatings of the the lowest porosity and good adhesion, which have been observed for all samples. The greatest thickness and the lowest porosity of alumina coatings were obtained at the deposition voltage of $30 \mathrm{~V}$, temperature of $30^{\circ} \mathrm{C}$, deposition time of $10 \mathrm{~min}$, from the suspension of $20 \mathrm{wt}$. $\%$ of alumina powder. The boehmite coatings of maximum thickness and the lowest porosity were electrodeposited at $4 \mathrm{~V}$ and deposition time of $30 \mathrm{~min}$ and treated at $1000{ }^{\circ} \mathrm{C}$ and $1300{ }^{\circ} \mathrm{C}$, forming $\gamma-\mathrm{Al}_{2} \mathrm{O}_{3}$ and $\alpha-\mathrm{Al}_{2} \mathrm{O}_{3}$ alumina coatings, respectively, at significantly lower sintering temperature. 
Acknowledgments. The author wishes to thank all co-workers who contributed with their work to obtain the experimental results presented in this review. Their names can be seen in our joint papers listed in the references. This research was financed by the Ministry of Education and Science, Republic of Serbia, contract No. III 45019.

\section{REFERENCES}

[1] S. Eraković, D. Veljović, P. N. Diouf, T. Stevanović, M. Mitrić, D. Janaćković, I. Z. Matić, Z. D. Juranić, V. Mišković-Stanković, The effect of lignin on the structure and characteristics of composite coatings electrodeposited on titanium, Prog. Org. Coat., 75, 275-283 (2012).

[2] A. R. Boccaccini, S. Keim, R. Ma, Y. Li, I. Zhitomirsky, Electrophoretic deposition of biomaterials, J. R. Soc. Interface, 7, 581-613 (2010).

[3] S. Eraković, A. Janković, D. Veljović, E. Palcevskis, M. Mitrić, T. Stevanović, D. Janaćković, V. Mišković-Stanković, The corrosion stability and bioactivity in simulated body fluid of silver/ hydroxyapatite and silver/hydroxyapatite/lignin coatings on titanium obtained by electrophoretic deposition, J. Phys. Chem. B, (2012) http://dx.doi. org/10.1021/jp305252a.

[4] C. Kaya, I. Singh, A. R. Boccaccini, Multi-walled carbon nanotube-reinforced hydroxyapatite layers on $\mathrm{Ti}_{6} \mathrm{~A}_{14} \mathrm{~V}$ medical implants by electrophoretic deposition (EPD), Adv. Eng. Mater., 10, 131-138 (2008).

[5] M. Cheon, I. Zhitomirsky, Electrodeposition of alginic acid and composite films, Colloids Surf. A, 328, 73-78 (2008)

[6] J. B. Bajat, V. B. Mišković-Stanković, J. P. Popić, D. M. Dražić, Adhesion characteristics and corrosion stability of epoxy coatings electrodeposited on phosphated hot-dip galvanized steel, Prog. Org. Coat., 63, 201-208 (2008).

[7] Z. Ž. Lazarević, V. B. Mišković-Stanković, Z. Kačarević-Popović, D. M. Dražić, Determination of the protective properties of electrodeposited organic epoxy coatings on aluminium and modified aluminium surfaces, Corros. Sci., 47, 823-834 (2005).

[8] F. Deflorian, S. Rossi, L. Fedrizzi, P. L. Bonora, EIS study of organic coating on zinc surface pretreated with environmentally friendly products, Prog. Org. Coat., 52, 271-279 (2005).

[9] F. Deflorian, S. Rossi, P. Kamarchik, L. Fedrizzi,
P. L. Bonora, Degradation mechanism of electrodeposited coatings in alkaline solution, Prog. Org. Coat., 47, 103-111 (2003).

[10] R. Boccaccini, J. Cho, T. Subhani, C. Kaya, F. Kaya, Electrophoretic deposition of carbon nanotube-ceramic nanocomposites J. Eur. Ceram. Soc., 30, 1115-1129 (2010).

[11] M. S. Djošić, V. B. Mišković-Stanković, Đ. T. Janaćković, Z. M. Kačarević-Popović, R. D. Petrović, Electrophoretic deposition and characterization of boehmite coatings on titanium substrate, Colloids Surf. A, 274, 185-191 (2006).

[12] M. S. Djošić, V. B. Mišković-Stanković, Z. M. Kačarević-Popović, B. M. Jokić, N. Bibić, M. Mitrić, S. K. Milonjić, R. Jančić-Heinemann, J. Stojanović, Electrochemical synthesis of nanosized monetite powder and its electrophoretic deposition on titanium, Colloids Surf. A, 341, 110 117 (2009)

[13] J. B. Bajat, V. B. Mišković-Stanković, M. D. Maksimović, D. M. Dražić, S. Zec, Electrochemical deposition and characterization of Zn-Co alloys and corrosion protection by electrodeposited epoxy coating on Zn-Co alloy, Electrochim. Acta, 47 4101-4112 (2002).

[14] Singh, C. Kaya, M. S. P. Shaffer, B. C. Thomas, A. R. Boccaccini, Bioactive ceramic coatings containing carbon nanotubes on metallic substrates by electrophoretic deposition, J. Mater. Sci., 41, 8144-8151 (2006).

[15] Zhitomirsky: Electrophoretic deposition of chemically bonded ceramics in the system $\mathrm{CaO}-\mathrm{SiO}_{2}$ $\mathrm{P}_{2} \mathrm{O}_{5}$, J. Mater. Sci. Lett., 17, 2101-2104 (1998).

[16] M. Guglielmi, A. Licculli, S. Mazzarelli, Thick composite coating via electrophoretic sol-gel processing, Ceram. Acta., 6, 19-25 (1994).

[17] H. Nishimori, M. Tatsumisago, T. Minami, Heattreatment effect of dispersed particles on the preparation of thick silica films by using electrophoretic sol-gel deposition, J. Mater. Sci., 31, 6529 (1996).

[18] X. Pang, I. Zhitomirsky, Electrophoretic deposition of composite hydroxyapatite-chitosan coatings, Mater. Charact., 58, 339-348 (2007).

[19] C. Kaya, F. Kaya, A. R. Boccaccini, Electrophoretic deposition infiltration of 2-D metal fibrereinforced cordierite matrix composites of tubular shape, J. Mater. Sci., 37, 4145 (2002).

[20] Z. Zhang, Y. Huang, Z. Jiang, Electrophoretic deposition forming of SiC-TZP composites in a nonaqueous sol media, J. Amer. Ceram. Soc., 77, 
1946-1949 (1994)

[21] Y. W. Song, D. Y. Shan, E. H. Han, Electrodeposition of hydroxyapatite coating on AZ91D magnesium alloy for biomaterial application, Mater. Lett., 62, 3276-3279 (2008).

[22] I. Corni, M. P. Ryan, A. R. Boccaccini, Electrophoretic deposition: From traditional ceramics to nanotechnology, J. Eur. Ceram. Soc., 28, 13531367 (2008).

[23] D. Stojanovic, B. Jokic, Dj. Veljovic, R. Petrovic, P. S. Uskokovic, Dj. Janackovic, Bioactive glassapatite composite coating for titanium implant synthesized by electrophoretic deposition, J. Europ. Ceram. Soc., 27, 1595-1599 (2007).

[24] K. Simović, V. Mišković-Stanković, D. Kićević, P. Jovanić, Electrophoretic deposition of thin alumina films from water suspension, Colloid Surf. A, 209, 47-55 (2002).

[25] M. S. Djošić, V. B. Mišković-Stanković, V. V. Srdić, Electrophoretic deposition and thermal treatment of boehmite coatings on titanium, $J$. Serb. Chem. Soc., 72, 275-287 (2007).

[26] M. S. Djošić, V. Panić, J. Stojanović, M. Mitrić, V. Mišković-Stanković, The effect of applied current density on the surface morphology of deposited calcium phosphate coatings on titanium, Colloid Surf. A, 400, 36-43 (2012).

[27] P. Sarkar, X. Haung, P. S. Nicholson, Structural ceramics microlaminates by electrophoretic deposition, J. Amer. Ceram. Soc., 75, 2907-2909 (1992).

[28] B. Ferrari, R. Morreno, Electrophoretic deposition of aqueous alumina slips, J. Eur. Ceram. Soc., 17, 549-556 (1997).

[29] I. Zhitomirsky, L. Gal-Or, A. Kohn, H. W. Hennicke, Electrodeposition of ceramic films from non-aqueous and mixed solutions, J. Mater. Sci., 30, 5307-5312 (1995).

[30] S. B. Abolmaali, J. B. Talbot, Synthesis of superconductive thin films of $\mathrm{YBa}_{2} \mathrm{Cu}_{3} \mathrm{O}_{7-\mathrm{x}}$ by a nonaqueous electrodeposition process, J. Electrochem. Soc., 140, 443-445 (1992).

[31] J. M. Park, S. I. Lee, K. W. Kim, D. J. Yoon, Interfacial aspects of electrodeposited conductive fibers/epoxy composites using electro-micromechanical technique and nondestructive evaluation, J. Colloid Interface Sci., 237, 80-90 (2001).

[32] E. de Beer, J. Duval, E. A. Meulenkamp, Electrophoretic deposition: A quantitative model for particle deposition and binder formation from alcohol-based suspensions, J. Colloid Interface Sci.,
222, 117-124 (2000).

[33] J. Y. Choudhary, H. S. Ray, K. N. Rai, Electrophoretic deposition of alumina from aqueous suspensions. trans, J. Br. Ceram. Soc., 81, 189-193 (1982).

[34] R. Fischer, E. Fischer, G. de Portu, E. Roncari, Preparation of ceramic micro-laminate by electrophoresis in aqueous system, J. Mater. Sci. Lett., 14, 25-27 (1995).

[35] A. R. Boccaccini, C. Kaya, Alumina ceramics based on seeded boehmite and electrophoretic deposition, Ceram. Int., 28, 893-897 (2002).

[36] O. O. Van der Biest, L. J. Vandeperre, Electrophoretic deposition of materials, Annu. Rev. Mater. Sci., 29, 327-352 (1999).

[37] P. Sarkar, P. S. Nicholson, Electrophoretic deposition (EPD): Mechanisms, kinetics and application to ceramics, J. Amer. Ceram. Soc., 79, 1987-2002 (1996).

[38] W. J. Dalzell, D. E. Clark, Thermophoretic and electrophoretic deposition of sol-gel composite coatings, Ceram. Eng. Sci. Proc., 7, 1014-1026 (1986).

[39] M. Lazić, V. B. Mišković-Stanković, P. Jovanić, K. Simović, The effect of bath temperature on the morphology of electrodeposited alumina films on steel, Interceram, 51, 328-332 (2002).

[40] K. Simović, V. B. Mišković-Stanković, D. Kićević, P. Jovanić, Characterization of alumina films electrodeposited on steel from water suspensions, Interceram, 52, 162-166 (2003).

[41] M. L. Guzmán-Castillo, X. Bokhimi, A. ToledoAntonio, J. Salmones-Blásquez, F. HernándezBeltrán, Effect of boehmite crystallite size and steaming on alumina properties, J. Phys. Chem. B, 105, 2099-2106 (2001).

[42] L. Aries, Preparation of electrolytic ceramic films on stainless steel conversion coatings, J. Appl. Electrochem., 24, 554-558 (1994).

[43] J. Temuujin, T. Jadambaa, K. J. D. Mackenzie, P. Angerer, F. Porte, F. Riley, Thermal formation of corundum from aluminium hydroxides prepared from various aluminium salts, Bull. Mater. Sci., 23, 301-304 (2000).

[44] P.A. Buining, C. Pathmamanoharan, J.B.H. Jansen, H.N.W. Lekkerkerker, Preparation of colloidal boehmite needles by hydrothermal treatment of aluminum alkoxide precursors, J. Am. Ceram. Soc., 74, 1303-1307 (1991).

[45] E. Morgado Jr., Y. L. Lam, L. F. Nazar, Formation 
of peptizable boehmites by hydrolysis of aluminum nitrate in aqueous solution, J. Colloid Interface Sci., 188, 257-269 (1997).

[46] S. Keysar, G. E. Shter, Y. Hazan, Y. Cohen, Heat treatment of alumina aerogels, Chem. Mater., 9, 2464-2467 (1997).

[47] J. M. Rousseaux, P. Weisbecker, H. Muhr, E. Plasari, Aging of precipitated amorphous alumina gel, Ind. Eng. Chem. Res., 41, 6059-6069 (2002).

[48] T. Tsukada, H. Segawa, A. Yasumori, K. Okada, Crystallinity of boehmite and its effect on the phase transition temperature of alumina, J. Mater.
Chem., 9, 549-553 (1999).

[49] X. Bokhimi, J. A. Toledo-Antonio, M. L. Guzmán-Castillo, B. Mar-Mar, F. Hernández-Beltrán, J. Navarrete, Dependence of boehmite thermal evolution on its atom bond lengths and crystallite size, J. Solid State Chem., 161, 319-326 (2001).

[50] W. D. Kingery, H. K. Bowen, D. R. Uhlmann, Introduction to Ceramics, John Wiley \& Sons, New York, 1975. 
